\title{
THE PARADOX OF PLASTICS IN HEALTHCARE AND HEALTH
}

\author{
Swaminathan Sivaram, Aditi Roy and Swapan K. Ray
}

\section{Introduction}

Plastics have emerged as one of the miracles of man-made materials, growing exponentially over the last seventy years. Plastics are high molecular mass polymers comprising mostly of carbon, hydrogen, nitrogen and oxygen, and often incorporate other lower molecular mass substances as additives to improve their functional properties. The use of plastics has brought deep-seated changes into the field of medicine by making healthcare safer and simpler, and are used in every phase of human healthcare: preventive, diagnostic, therapeutic, prosthetic and palliative (Maitz, 2015). Yet, paradoxically, the same material has been at the receiving end of civil society's wrath for contributing to environmental as well as public health hazards. This chapter will:

1. Examine the science-based evidence on the paradox of plastics.

2. Seek out solutions to exploit the beneficial use of plastics in healthcare while minimising their adverse impact on health and the environment.

3. Lay out the challenges in finding these solutions, including safe end-oflife solutions for plastics used in healthcare, safety of chemicals used and sustainable alternatives for plastic products in healthcare.

4. Re-examine the legacy application of plastics in healthcare and explore how to create new solutions which can resolve the paradox of plastics effectively.

\section{An introduction to plastics}

Plastics are a class of organic materials, synthetic or semi-synthetic, malleable in nature and can be shaped into objects by the application of heat and pressure. They are primarily comprised of polymers which are longchain organic molecules with high molecular mass (macromolecules) built from smaller repeating units called monomers. Monomers are commonly derived from petrochemicals. The organised plastic manufacturing industry began in 1950 and grew rapidly, fuelled by increasing consumer acceptance. 
The global manufacturing capacity for plastics is about 360 million tons today, exceeding that of steel by volume. Plastics are pervasive in our everyday life in a wide range of applications to such an extent that life on earth today cannot be imagined without the use of plastics.

Most plastics are durable and degrade very slowly, as their chemical structure renders them resistant to many natural processes of degradation. By one estimate, the cumulative human production of plastics is 8.3 billion tons, of which 6.3 billion tons have ended up as waste. It is estimated that $50-80 \%$ of debris in marine environments are of plastic origin (Geyer, Jambeck and Law, 2017).

Plastics have a potential effect on greenhouse gas emissions, climate change and health (Azoulay et al., 2019; Kumar, 2018). The production, management and incineration of plastics added 860 million tons of $\mathrm{CO}_{2}$ (or equivalent greenhouse gases) to the atmosphere in 2019, equal to the emissions from almost 200 typical coal-fired power stations. For comparison, global $\mathrm{CO}_{2}$ emissions exceeded 36 billion tons in 2019. The carbon footprint of plastics is expected to triple in size by 2050 . Plastics are generally made from petroleum and natural gas, which are non-renewable fossil fuels. However, it must be noted that the manufacturing of plastics leaves a relatively smaller carbon footprint as compared to other industrial sectors, such as the generation of power from coal or natural gas, manufacture of glass, steel, paper, aluminium or cement. Additionally, plastics are far lighter in weight and hence more efficient to transport in terms of fuel consumed. These two benefits taken together results in a lower carbon footprint for plastics when compared to equivalent products made from glass, paper or aluminium during the life-cycle of their application (Amienyo et al., 2013; Brandt and Pilz, 2011).

\section{The role of plastics in healthcare}

\section{Materials, applications and desirable functional properties}

Plastics bring many benefits to medicine and public health because they are low-cost, efficient, unbreakable, easy to transport, can be sterilised, and can be processed into intricate shapes and forms. A representative list of plastics used in medical applications is shown in Table 21.1. Irrespective of the chemical composition of the plastic, there are a few properties that are critical to medical applications, these being (a) mechanical strength (b) flexibility and softness (c) chemical inertness (d) moisture barrier (e) transparency (f) weathering resistance (g) ability to use accepted sterilisation techniques without loss of physical properties and (h) ability to process the plastics into intricate shapes. For polymers that come into contact with body parts and fluids, there are additional functionalities such as (a) biocompatibility (no adverse reactions to body tissues) (b) non-cytotoxicity (is not carcinogenic), and (c) antithrombogenicity (incapable of clotting blood) if the 
material is likely to come into contact with blood and (d) non-allergenic, if skin contact is required.

\section{Common additives used in plastics for healthcare}

Plastics products used in healthcare invariably require the use of additives to enhance their useful functional properties. Examples are the use of plasticisers to render polyvinyl chloride (PVC) soft and flexible, the use of antioxidants and anti-UV additives to make polyethylene $(\mathrm{PE})$ and polypropylene (PP) able to withstand oxidative and light-induced ageing, additives used to make plastics capable of being sterilised using $\gamma$-ray radiation, to make them more transparent for better visibility (clarifiers and nucleating agents), to make them opaque to X-ray as well as to render them anti-microbial and increase the lubricity. Additives are added either prior to or during the processing and shaping of the plastic, under the influence of temperature and shear forces. Additives tend to leach out into fluids that come in contact with the plastic. The safety of chemicals used as additives has come under intense scrutiny in recent times, thanks to a better understanding of how trace organic chemicals interact with living biological systems, and how chemicals alter human cells down to the genetic, genomic and DNA level.

\section{Life cycle analysis and end-of-life solutions}

The increasing penetration of plastics into healthcare and medical devices applications is also generating substantial quantities of disposed wastes. By their very nature, in such applications, plastics qualify as "single-use" materials. Since such products may have come into contact with pathogens and other biological hazards, they are classified as "hazardous wastes." Thus, while plastics play an invaluable role in healthcare, they are also often reviled for the negative consequences they have on the environment as well as on human health.

The Biomedical Waste Management Rules 2016 and subsequent modifications thereof mandate incineration of discarded medicines, body parts, and disposable plastics contaminated with blood or body fluids. These are put in yellow-coloured bags/bins for incineration. Other waste plastics packed in red-coloured bags/bins are categorised as recyclables. When it comes to disposal of medical waste, incineration has a number of benefits, such as the prevention of disease transmission and a large reduction in the volume and weight of the waste. However, incineration increases the $\mathrm{CO}_{2}$ load on the environment, as discussed in the chapter titled Sustainable Ways to Manage Waste in Healthcare Facilities.

The incineration of chlorinated plastics (e.g. PVC) is known to result in hazardous emissions unless they are incinerated with special care. Significant human health hazards, particularly from the release of carcinogenic air toxins such as dioxins and polychlorinated dibenzo-dioxins/polychlorinated 
Table 21.1 Representative list of plastics used in medical applications

\begin{tabular}{|c|c|c|}
\hline S. No & Plastic Type & Application Area \\
\hline 1 & $\begin{array}{l}\text { Low-density polyethylene, very } \\
\text { low-density polyethylene }\end{array}$ & Flexible clear tubing, packaging films \\
\hline 2 & Polyvinyl chloride & $\begin{array}{l}\text { Flexible clear tubing, blood bag, } \\
\text { blood tubing, flexible pouches for } \\
\text { intravenous fluids }\end{array}$ \\
\hline 3 & $\begin{array}{l}\text { Polyvinyl chloride, cyclic olefin } \\
\text { copolymers }\end{array}$ & $\begin{array}{l}\text { Blister packaging for } \\
\text { pharmaceuticals (tablets and } \\
\text { capsules) }\end{array}$ \\
\hline 4 & $\begin{array}{l}\text { Polypropylene, high-density } \\
\text { polyethylene, cyclic olefin } \\
\text { copolymers }\end{array}$ & $\begin{array}{l}\text { Syringe housings, pre-filled syringes, } \\
\text { inner lining of catheters, graft for } \\
\text { craniofacial contour } \\
\text { augmentation, ocular surgical aids }\end{array}$ \\
\hline 5 & Polyethene terephthalate & $\begin{array}{l}\text { Rigid transparent tubes for blood } \\
\text { collection, vascular graft, surgical } \\
\text { meshes }\end{array}$ \\
\hline 6 & $\begin{array}{l}\text { Polymethyl methacrylate, } \\
\text { Polycarbonate, polyesters } \\
\text { containing cycloaliphatic diols, } \\
\text { glycol modified polyethylene } \\
\text { terephthalate, polysulfone }\end{array}$ & $\begin{array}{l}\text { Transparent components of medical } \\
\text { devices and instruments, clamps, } \\
\text { face shields, IV connectors, blood } \\
\text { filters, renal dialysis equipment, } \\
\text { containers }\end{array}$ \\
\hline 7 & Polycarbonate-ABS blends & $\begin{array}{l}\text { Ventilators, anaesthesia machines, IV } \\
\text { tube connectors, thermometers }\end{array}$ \\
\hline 8 & Polytetrafluoroethylene & $\begin{array}{l}\text { Catheter linings and multi-lumen } \\
\text { tubing, soft tissue generation } \\
\text { patches, vascular grafts, surgical } \\
\text { meshes, tendon repair materials }\end{array}$ \\
\hline 9 & Polyether sulfone & $\begin{array}{l}\text { Single and multi-lumen tubing, } \\
\text { catheters }\end{array}$ \\
\hline 10 & $\begin{array}{l}\text { Sulfonated polyacrylonitrile, } \\
\text { polysulfone, } \\
\text { polyarylethersulfone }\end{array}$ & Dialysis membranes \\
\hline 11 & Poly (4-methyl pentene-1) & $\begin{array}{l}\text { Membranes for extracorporeal } \\
\text { "protective ventilators" for } \\
\text { oxygen-carbon dioxide exchange } \\
\text { in blood }\end{array}$ \\
\hline 12 & $\begin{array}{l}\text { Ultra-high molecular weight } \\
\text { polyethylene, Polyether ether } \\
\text { ketone }\end{array}$ & $\begin{array}{l}\text { Heart valve, artificial tendons, } \\
\text { low-friction orthopaedic surgical } \\
\text { implants, hip replacements }\end{array}$ \\
\hline 13 & Polyurethanes & Breathable wound dressings \\
\hline 14 & $\begin{array}{l}\text { Polyethylene and polypropylene } \\
\text { nonwovens (melt blown and } \\
\text { spun bonded) }\end{array}$ & $\begin{array}{l}\text { Disposable gowns, face masks, head } \\
\text { and shoe covers, blue wraps for } \\
\text { wrapping sterilised hospital tools }\end{array}$ \\
\hline 15 & Natural rubber, nitrile rubber & Surgical gloves, condoms \\
\hline 16 & Thermosetting polycarbonates & Prescription eye lenses \\
\hline 17 & $\begin{array}{l}\text { Polystyrene, cyclic olefin } \\
\text { copolymers }\end{array}$ & $\begin{array}{l}\text { Medical diagnostics, Elisa well and } \\
\text { microtiter plates }\end{array}$ \\
\hline 18 & Variety of clear plastic films & $\begin{array}{l}\text { Pharmaceutical packaging, shrink } \\
\text { wraps, child safe closures }\end{array}$ \\
\hline
\end{tabular}


Table 21.1 (Continued)

\begin{tabular}{|c|c|c|}
\hline S. No & Plastic Type & Application Area \\
\hline 19 & $\begin{array}{l}\text { Polystyrene-b-polyisobutylene- } \\
\text { polystyrene block copolymers }\end{array}$ & Coating on drug-eluting stents \\
\hline 20 & $\begin{array}{l}\text { Ethylene copolymers, } \\
\text { polyurethanes silicones, } \\
\text { natural polymers }\end{array}$ & $\begin{array}{l}\text { Wound healing gauzes, fluid } \\
\text { adsorbent gauzes }\end{array}$ \\
\hline 21 & $\begin{array}{l}\text { Polyethylene glycols, } \\
\text { polyvinylpyrrolidone, } \\
\text { polyvinyl alcohol }\end{array}$ & Anti-fouling coatings on catheters \\
\hline 22 & $\begin{array}{l}\text { Polyamide, polypropylene, } \\
\text { polyethylene terephthalate, } \\
\text { polyglycolic acid, } \\
\text { polydioxanone }\end{array}$ & $\begin{array}{l}\text { Non absorbable and absorbable } \\
\text { surgical sutures }\end{array}$ \\
\hline 23 & $\begin{array}{l}\text { Polydimethylsiloxane, poly } \\
\text { hydroxyethyl methyl acrylate }\end{array}$ & Intraocular lenses \\
\hline 24 & Polyamides & $\begin{array}{l}\text { Balloon of catheters, ligament and } \\
\text { tendon repair materials }\end{array}$ \\
\hline 25 & Polylactic acid & $\begin{array}{l}\text { Bio-absorbable orthopaedic implant } \\
\text { materials for knee and hip } \\
\text { reconstructive surgery }\end{array}$ \\
\hline
\end{tabular}

dibenzofurans (PCDD/PCDF) have been reported. Incineration also produces ashes containing toxic metals which can find their way into groundwater aquifers. Although there have been great benefits from using plastics in the healthcare sector, there is a need to undertake rigorous life-cycle studies which are factored into the production and disposal decisions for plastics in this sector.

This creates a sad juxtaposition; on one hand, plastics deliver life-saving care to patients, but once used, their disposal contributes negatively to health and the environment. This indeed is the paradox of plastics in healthcare and health. The real challenge is to manage the good, bad and ugly faces of plastic in a rational and informed manner (North and Halden, 2013).

\section{The impact of plastics on human health}

While plastics, in general, are considered safe for human health, some of them are reported to cause adverse effects when used in specific applications. They result from two factors: degradation and leaching. The health risks are further compounded by indiscriminate use and improper disposal. Attributing direct cause-and-effect links or indirect risks of plastic use on human health and diseases are challenging. Great progress has been made in recent years, through animal models and epidemiological studies, in understanding the risks posed by plastics to environment, biological systems and human health (Halden, 2010; Rodrigues et al., 2019). Health risk assessments are critical not only for informing policy and regulations but 
also for developing alternatives that are functionally effective, yet safe for the environment and public health.

Bisphenol-A (BPA), which can be formed during degradation of aromatic polycarbonates, has been implicated in a host of adverse health effects, including reductions in fertility and birth weight, male genital abnormalities, altered behavioural development, diabetes, heart disease and obesity. Although underlying mechanisms through which individual chemicals interact with biological systems vary, it is recognised that BPA is an endocrine disrupting chemical (EDC). The human biological system has many endocrine glands that produce hormones essential for a wide range of bodily functions such as reproduction, growth, development, immunity, and functioning of brain and nervous system. Therefore, by their actions, many EDCs have been confirmed or suspected in their roles in development of reproductive, immunological, genetic and neurological toxicities (Rochester, 2013).

Establishing a clear connection between a chemical compound such as BPA, and human health, is not easy. Most studies are restricted to various cell- or animal-based models. The question of whether constant long-term exposure, albeit in small quantities, has any adverse effect on human health invariably goes unanswered (Glausiusz, 2014). Nevertheless, many countries have, as a matter of abundant caution, prohibited the use of PC in specific applications such as reusable water bottles, feeding bottles and food containers used by infants.

Another chemical that has come under significant scrutiny by the regulators is di-(2-ethylexyl) phthalate (DEHP or DOP) which is used as a plasticiser in PVC. Since in this application, PVC comes in contact with blood or liquids that are ingested, safety issues associated with DOP assumes importance (Tickner et al., 2001). DEHP has been characterised as a "possible human carcinogen" by the International Agency for Research on Cancer (IARC) with most evidence pointing towards a possible link with breast cancer. Other health outcomes that are frequently studied are childhood asthma, adult cardio-metabolic diseases such as type- 2 diabetes, heart disease, hypertension, cholesterol levels, liver function, childhood and adult obesity, thyroid-related disorders and compromised immune function. These toxic effects were observed upon oral uptake, but not upon parenteral administration, because lipid bi-layers appear necessary for the dissolution and release of DOP.

The process of identifying an alternative and establishing its safety, de novo, in application is expensive and time-consuming. In the meantime, use of phthalate-based PVC continues to be used in medical applications, especially blood bags and tubing, since there are no seemingly effective and affordable alternatives. This is a case where the benefits seem to outweigh the risks. 


\section{Resolving the paradox of plastics in healthcare and health}

Resolving the paradox of plastics in healthcare and health requires a multipronged intervention:

(a) material substitution strategy, especially where the life cycle of the material in use is short

(b) better product design for safety in use as well as disposal

(c) better understanding of the mammalian response to chemicals and their mixtures

(d) technology to reuse plastics in medical applications after de-contamination.

Every plastic currently being used in medical applications must be subjected to careful analysis in terms of its strengths and weaknesses and alternatives sought for substitution, where possible. Technology is available today to replace PVC containing plasticisers with high co-monomer content polyethylene elastomers. This eliminates the need for plasticiser and, thereby, the hazards of PVC. Several safer substitutes for DOP are also now available. Biodegradable and biocompatible plastics can be disposed of under controlled composting conditions. Some of these are suitable for replacing the currently used fossil fuel-derived plastics in medical applications. Predictive heuristics to understand mammalian responses to chemicals, based on big data and AI-based tools are emerging which may make future choice of materials for medical applications more rational and evidence based (Wambaugh et al., 2014). Chemistry and chemical engineering, which form the foundations of the plastic industry, by its very nature, have been largely reductionist. While reductionism has resulted in tremendous advances in material science, it has also caused unintended consequences on human health and environment. To resolve the paradox, it is necessary to combine our present knowledge and understanding with integrative systems thinking leading to product design for inherency, life-cycle and function (Anastas, 2019).

The problem is not limited to simply avoiding plastics that have been linked with health hazards and substituting them with safer alternatives. More fundamental changes in the design, application, re-use and disposal of plastics are necessary. Issues that need to be considered when evaluating use of plastics in health care are choosing materials based on a careful understanding of risks and benefits, in the short and long-term, using hard scientific data. Rigorous cradle-to-grave life cycle studies should be undertaken as alternatives to conventional petroleum-based plastics emerge, as well as risk assessments before adopting them in practice. This will ensure that the alternatives truly serve to reduce adverse effects without any 


\section{Box 21.1 Case study}

\section{Plastics in healthcare in the time of COVID-19}

In the fight against SARS-CoV-2, plastics played an indispensable role in protecting both the patient and the medical service professional. The sample collection vials and container, the swabs and the petridishes are derived from plastics. Surgical face masks are made with non-woven fabrics, which has better pathogen filtration capabilities and air permeability. Body overalls, gowns, caps and linens are made from non-woven PE and PP fabric. Goggles and visors are made from polycarbonates (PC) or polymethyl methacrylate (PMMA). Every country of the world rapidly scaled up their production of PPEs. The WHO requested a $50 \%$ escalation of disposable PPE production (Tullo, 2020).

The resulting plastic wastes were also a cause for concern. Hospitals generated much more waste as compared to normal times and rapidly ran out of space to store waste PPEs. It is reported that the city of Wuhan in China produced more than 240 tons of single-use plastics waste per day at the peak of the pandemic (Adyel, 2020). Incinerator capacities were woefully inadequate to cope with the increasing load of wastes. This extra pressure also led to inappropriate and unacceptable waste disposal methods. The prioritisation of human health over environmental health in these unprecedented times has likely set back public policies to minimise the use of single-use plastics and is a stark illustration of the paradox of plastics in healthcare.

unintended consequences. There is a clear case for developing degradable or compostable plastics for single-use applications with a programmed, short lifespan. Finally, in order to reduce plastic use to the bare minimum that cannot be achieved by non-plastic substances, healthcare professionals, like everyone else, should review and modify their use of plastic in their personal and professional lives (Box 21.1).

\section{Key takeaways}

- The healthcare sector provides an opportunity to develop strategies for more sustainable consumption and disposal of plastic materials.

- Examples of reducing single-use plastics in hospital environments, reprocessing medical equipment for multiple uses and switching to alternative plastics which have no negative environmental impact are already emerging. 
- These interventions could help realise the full potential of plastics in healthcare and public health and eventually lead to sustainable manufacturing and consumption of plastics in healthcare with a minimum impact on health.

\section{References}

Adyel, T. M. (2020). Accumulation of plastic waste during COVID-19. Science, 369, (11), September, 1314.

Amienyo, D., Gujba, H., Stichnothe, H., \& Azapagic, A. (2013). Life cycle environmental impacts of carbonated soft drinks. International Journal of Life Cycle Assessment, 18, 77-92.

Anastas, P. T. (2019). Beyond reductionist thinking in chemistry for sustainability. Trends in Chemistry, 1, 145-148. doi:10.1016/j.trechm.2019.03.007

Azoulay, D., Villa, P., Arellano, Y., Gordon, M., Moon, D., Miller, K., \& Thompson, K. (2019). Plastic and health: The hidden costs of a plastic planet (1-74). https:// www.ciel.org/plasticandhealth/

Brandt, B., \& Pilz, H. (2011). The impact of plastic packaging on life cycle energy consumption and greenhouse gas emissions in Europe (1-7). Denkstatt GmbH.

Geyer, R., Jambeck, J. R., \& Law, K.L. (2017). Production, use, and fate of all plastics ever made. Science Advances, 3(7), e1700782. https://www.science.org/doi/ full/10.1126/sciadv.1700782

Glausiusz, J. (2014). The plastics puzzle. Nature, 508, 306-308.

Halden, R. U. (2010). Plastics and health risks. Annual Review of Public Health, 31, 79-194.

Kumar, P. (2018). Role of plastics on human health. Indian Journal of Pediatrics, 85, 384-389.

Maitz, M. F. (2015). Applications of synthetic polymers in clinical medicine. Biosurface and Biotribology, 1, 161-176. doi: 10.1016/j.bsbt.2015.08.002.

North, E. J., \& Halden, R. U. (2013). Plastics and environmental health: The road ahead. Reviews on Environmental Health, 28, 1-8.

Rochester, J. R. (2013). Bisphenol A and human health: a review of the literature. Reproductive Toxicology, 42, 132-155.

Rodrigues, M. O., Abrantes, N., Gonçalves, F. J. M., Nogueira, H., Marques, J. C., \& Gonçalves, A. M. M. (2019). Impacts of plastic products used in daily life on the environment and human health: What is known? Environmental Toxicology and Pharmacology, 72, 103239-103273.

Tickner, J. A., Schettler, T., Guidotti, T., McCally, M., Rossi, M. (2001). Health risks posed by use of di-2-ethylhexyl phthalate (DEHP) in PVC medical devices. American Journal of Industrial Medicine, 39, 100-111.

Tullo, A. H. (2020). Plastics during the pandemic. C\&EN, 98.

Wambaugh, J. F., Wang, A., Dionisio, K. L., Frame, A., Egeghy, P., Judson, R., \& Woodrow Setzer, R. W. (2014). High throughput heuristics for prioritizing human exposure to environmental chemicals. Environmental Science \& Technology, 48, 12760-12767. 